Article

\title{
Fabrication of Poly(pentaerythritol tetrakis (3-mercaptopropionate)/dipentaerythritol penta-/hexa-acrylate)HIPEs Macroporous Scaffold with Alpha Hydroxyapatite via Photopolymerization for Fibroblast Regeneration
}

\author{
Muhammad Imran Azman ${ }^{1}{ }^{1}$, Nunthawan Kwangsawart ${ }^{1}$, Jitima Preechawong ${ }^{1}$, \\ Manit Nithitanakul ${ }^{1, *(D)}$ and Pornsri Sapsrithong ${ }^{2}$ \\ 1 The Petroleum and Petrochemical College, Chulalongkorn University, Phayathai Road, Chula Soi 12, \\ Pathumwan, Bangkok 10330, Thailand; muhammadimranazman@gmail.com (M.I.A.); \\ cottonmy@hotmail.com (N.K.); jitima.pre@gmail.com (J.P.) \\ 2 Department of Mechanical Engineering Technology, College of Industrial Technology, King Mongkut's \\ University of Technology North Bangkok, 1518 Pracharat 1 Road, Wongsawang, Bangsue, Bangkok 10800, \\ Thailand; pornsri.s@cit.kmutnb.ac.th \\ * Correspondence: manit.n@chula.ac.th
}

Received: 26 June 2020; Accepted: 14 August 2020; Published: 24 August 2020

check for updates

\begin{abstract}
Synthetic biomaterials that can be structured into porous scaffolds for support cell growth have played a role in developing the field of tissue engineering. This research focused on combination of biodegradable emulsion template along with the assisting of low-cost polymerization reaction. The appendage of ester-based surfactant, Hypermer B246, played a vital role which gave an outstanding dispersion in HIPEs system and degradability. PolyHIPEs were prepared by using domestic ultraviolet light source for producing a multiscale porosity material. The morphology showed a promising result of poly(pentaerythritol tetrakis (3-mercaptopropionate)/dipentaerythritol penta-/hexa-acrylate)HIPEs with varied Hypermer B246 surfactant concentration resulting in the pores size increased in between $51.2 \pm 9.8 \mu \mathrm{m}$ to $131.4 \pm 26.32 \mu \mathrm{m}$. Cellular moieties of poly(TT/DPEHA) HIPEs were confirmed by using SEM while inclusion of hydroxyapatite were confirmed by SEM, FTIR and EDX-SEM and quantified by thermogravimetric analysis. The maximum stress and compressive modulus of the obtained materials were significantly enhanced with HA up to five percent by weight. Poly(TT/DPEHA)HIPEs with HA showed the ability for the cell attachment and the adhesion/proliferation of the cells, suggested that poly(TT/DPEHA) HIPEs with HA were suitable for biomaterial application.
\end{abstract}

Keywords: PolyHIPEs; biomaterial; photopolymerization; fibroblast; ultraviolet

\section{Introduction}

Emulsions are heterogeneous mixtures of at least one immiscible liquid dispersed in another in the form of droplets [1]. In most cases, at least one of the liquids will be water or an aqueous solution. An emulsion is often described as oil-in-water $(\mathrm{O} / \mathrm{W})$ or water-in-oil $(\mathrm{W} / \mathrm{O})$ where the first phase mentioned refers to the internal (or dispersed) phase. Emulsion templating is one of the methods for developing porous materials stabilized by the presence of surfactant. This method always involved for the formation of high-internal-phase-emulsions (HIPEs) which comprised of the internal phase more than $74 \%$ of the total volume of the system [2]. Emulsion templating is a flexible and easily controlled method for fabrication of mesopore and macropore materials (pore size range 5-100 $\mu \mathrm{m}$ ). If a less 
concentrated emulsion is used (internal phase volume $<60 \%$ ), a more closed-cell porous structure will be obtained [3].

PolyHIPEs typically consisted of two phases which are an oil phase (monomer, initiator, surfactant, solvent and some additive such as porogenic solvent, filler, etc.) and an aqueous phase (water, electrolyte and surfactant). High-internal-phase-emulsion (HIPE) polymerization can be applied for the preparation of macroporous polymers [4], which are low density, abundance open cellular structures, high interconnected porosity and large surface area and suitable for drug encapsulation, catalyst support, porous support, stationary phase, tissue engineering and bio-related applications [2].

Most polyHIPE preparation involves conventional, thermally initiated polymerization. A large fraction of contemporary polyHIPE research and development has focused on expanding the library of novel monomers that can be used for polyHIPE development. Often, novel monomers have been incorporated within polyHIPEs through the adaptation of a variety of novel polymerization mechanisms. PolyHIPEs have been prepared by using thermal cure initiators, but because of the slow rate of reaction, other faster reaction mechanisms are becoming more interesting. As an alternative to thermal initiation, photo initiation has been introduced. Typically, this type of reaction is more rapid and able to complete the reaction rapidly. It is more interesting for researcher to focus on photo initiation polymerization [5].

Photo initiators are activated by UV light, which generates free radicals for starting the polymerization reaction. Pore size and porosity significantly affect the properties of the materials comprising of morphology, mechanical and surface properties [6,7]. In addition, the properties of polyHIPE usually depend on surfactant concentration, type of surfactant, additives, temperature of aqueous phase, water fraction, monomer ratio and type of polymerization [8]. Various polymerization methods have been investigated to prepare the porous polymer, including surfactant-catalyzed free-radical polymerization, controlled-radical polymerization (activators generated by electron transfer atom transfer radical polymerization, AGET ATRP) and reversible addition fragmentation chain-transfer polymerization (RAFT) polymerization, ring-opening metathesis polymerization (ROMP), ring-opening polymerization (ROP), Diels-Alder polymerization and thiol-ene click chemistry [9].

Thiol-ene click chemistry has been applied extensively in several applications. Acrylate monomers are employed in thiol-ene reactions, which contain residual thiols in function materials [10]. Residual thiols have been found in thiol-acrylate polyHIPE materials prepared with different thiol:acrylate stoichiometries - even when the acrylate groups were in significant excess. Thus, multifunctional acrylates of polyHIPE have been prepared by photopolymerization [11].

Highly-porous polymers (polyHIPEs) have been prepared by the photopolymerization of high-internal-phase-emulsions (HIPEs) with varying ratios of thiol and acrylate monomers. The resulting polymers have a nominal porosity of $80 \%$ and have been seen to have a well-defined, interconnected pore morphology with average-sized diameters. Photopolymerization has some selected advantages over thermally activated polymerization. For example, using photo polymerization such as the ultraviolet ray would increase the polymerization over time. Photo-polymerization also reduces the utilization of energy and exploitation of chemical polymerization reactions [12].

Hydroxyapatite (HA) has been used clinically for many years. It has good biocompatibility in bone contact as its chemical composition is similar to that of bone material. HA is a mineral component in inorganic phase of human hard tissue which is bioactive, supports bone ingrowth properties and excellent biocompatibility with hard tissue. From these properties, HA is extensively used as the substitution materials for artificial bones [13]. However, the limitation of HA is low mechanical strength, which lead to incorporate HA with biocompatible polymer [14]. HA has hard and stiff characteristics which make it widely used as an inorganic filler to improve the mechanical strength of a polymer materials [15]. Moreover, nano-hydroxyapatite/polymer composite increased mechanical properties and improved the protein adsorption capacity [16].

The aim of this study is to demonstrate the preparation of degradable polyHIPEs from thiol-ene reaction for bone tissue template. In addition, the main purpose of this study is to investigate the effect 
of HA concentration towards the biocompatibility, mechanical strength, thermal stability degradability and morphologic properties of the polyHIPEs. The feasibility of adding hydroxyapatite towards polyHIPEs improve biocompatibility of the polyHIPEs and mechanical properties which are vital for the better tissue engineering research. As far as we concern, this research emphasizes the usage of degradable monomers such as DPEHA and TT is shown in Figure 1. Interestingly, this research also emphasized the incorporation of ester-based surfactant Hypermer B246 due to its dispersion behavior in the emulsion system and abundance of ester bonds which make it easy to degrade. The surfactant Hypermer B246 was chosen not only because of its chemical nature, but it also emulsified efficiently in the polyHIPEs system. In addition, ultraviolet (UV) light was favored because of the more rapid radical polymerization and able to complete the reaction in a shorter time compared to the conventional method. It was very interesting to further explore the preparation of degradable polyHIPEs using photopolymerization such as UV light for bone cell cultures template.
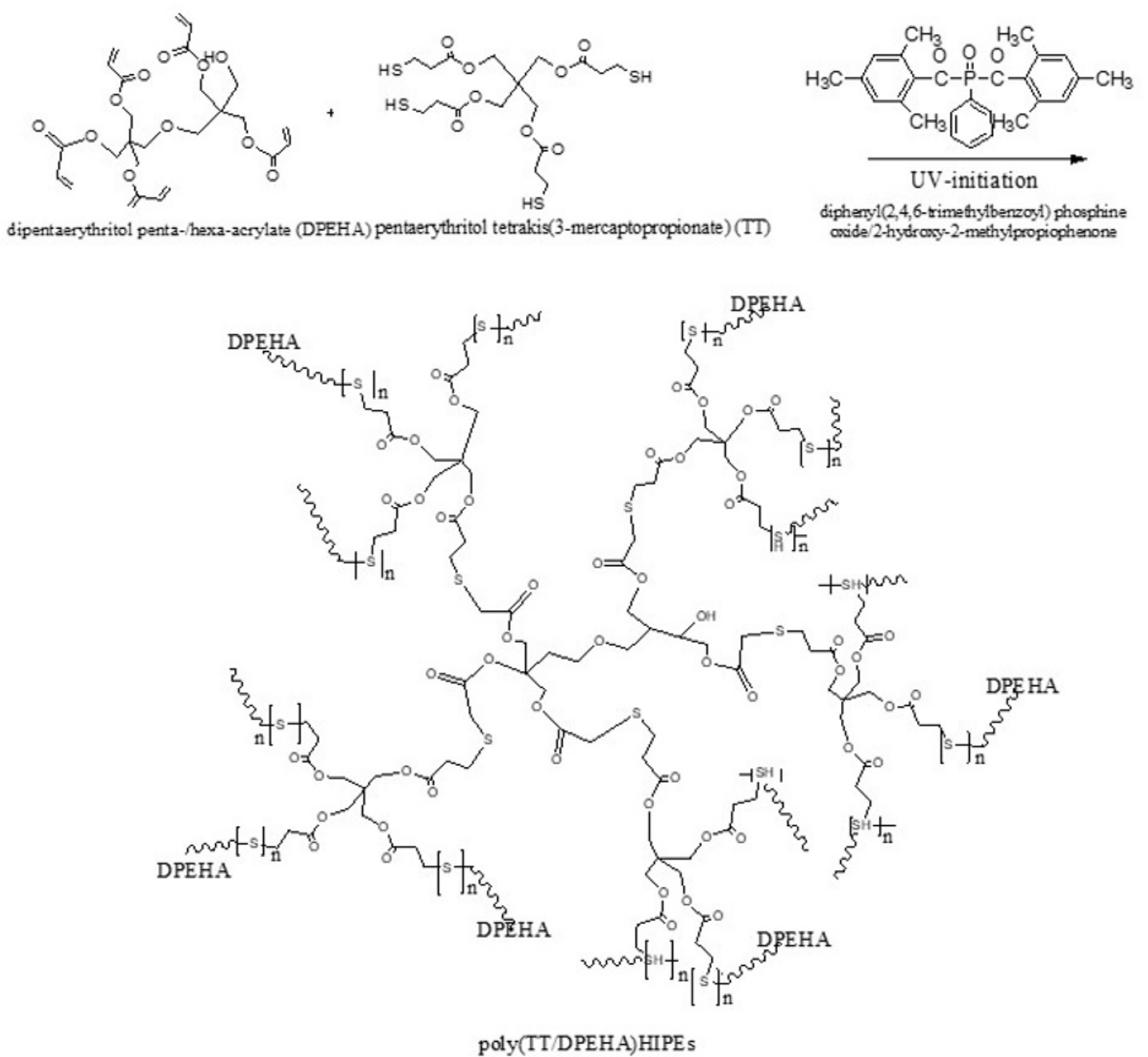

Figure 1. Schematic of poly(TT/DPEHA)HIPEs molecular structure.

\section{Experimental}

\subsection{Materials}

The chemicals used in preparation of polyHIPE were pentaerythritol tetrakis (3-mercaptopropionate) (TT), dipentaerythritol penta-/hexa-acrylate (DPEHA) as monomers, diphenyl (2,4,6-trimethylbenzoyl) phosphine oxide/2-hydroxy-2-methylpropiophenone blend as an initiator and hydroxyapatite (HA) purchased from Sigma Chemical Co. (St. Louis, MO, USA). Surfactant used in 
the study was Hypermer B246 obtained from Croda. The stabilizer, calcium chloride $\left(\mathrm{CaCl}_{2}\right.$, purity $\geq$ 97\% (KT)), was purchased from Fluka. The 1,2-dichloroethane (AR grade) and methanol (AR grade) purchased from RCI Labscan, Thailand were used as a solvent in soxhlet extraction.

\subsection{Methodology}

Preparation of Poly(TT/DPEHA/HA)HIPEs

The required amount of Hypermer B246 (2.5, 2.7, and $3 \mathrm{wt} \%$ of organic phase) was dissolved by 1,2-dichloroethane in a multi-neck flask. Then, TT and DPEHA (organic phase) were added in the ratio of $60: 40$ by volume and stirred at $300 \mathrm{rpm}$ with a magnetic bar. Diphenyl (2,4,6-trimethylbenzoyl) phosphine oxide/2-hydroxy-2-methylpropiophenone (initiator) was added to the solution and stirred well. After that, the aqueous phase which composed of distilled water, $\mathrm{CaCl}_{2}$ and $\mathrm{HA}(0,5,10$, $15 \mathrm{wt} \%$ ) was added dropwise into the multi-neck flask. The emulsion was homogenized for 10-15 min. The emulsion of organic phase and aqueous phase was poured into a cylindrical glass vial and further polymerized in the UV chamber with a power output $25 \mathrm{~W} / \mathrm{cm}^{2}$. Polymerized material was removed from the vials and the remained monomers were extracted using methanol for $6 \mathrm{~h}$ before dried in a convection oven at $60^{\circ} \mathrm{C}$ for $48 \mathrm{~h}$.

\subsection{Characterizations}

\subsubsection{Morphologic and Chemical Properties}

Surface morphology of the polyHIPEs was investigated by FE-SEM (Hitachi S-4800, Tokyo, Japan) at the voltage of $2.0-5.0 \mathrm{kV}$. Samples were coated with platinum on a sputter coater prior to the analysis. ATR-FTIR spectra of the samples were obtained by using the Thermo Scientific Nicolet iS5. The selected spectrum resolution and scanning range employed were $4 \mathrm{~cm}^{-1}$ and $4000-600 \mathrm{~cm}^{-1}$, respectively. The FTIR spectra with percentage transmittance versus wavelength $\left(\mathrm{cm}^{-1}\right)$ were acquired after the scanning process. In addition, thermal properties with DTG data were collected by using NETZSCH STA 449 F3 Jupiter instrument. Samples were placed in the alumina crucible and heated from 40 to $800{ }^{\circ} \mathrm{C}$, at heating rate of $10^{\circ} \mathrm{C} / \mathrm{min}$ under $\mathrm{N}_{2}$ flow of $100 \mathrm{~mL} / \mathrm{min}$. The degradation temperature was determined at weight loss of $50 \%$ from weight loss versus temperature curve.

\subsubsection{Mechanical Properties}

Lloyd Universal Testing Machine (Lloyd Ametek LRX Tensile Tester, San Diego, CA, USA) was used to measure the mechanical properties of all samples in compression mode. Cylinder shape test specimens, $2.54-\mathrm{cm}$-diameter $\times 2.54-\mathrm{cm}$ in length, were prepared. A speed of $0.127 \mathrm{~cm} / \mathrm{min}$ and $500-\mathrm{N}$ load cells were used for all measurements. The value of the compression stress and Young's modulus were determined from an average of five samples. Degradation test of polyHIPEs was investigated according to ASTM F1635. The samples were cut into $0.5 \times 0.5 \times 0.5 \mathrm{~cm}$ for the tests. The samples were fully dried for $48 \mathrm{~h}$ and weighed prior to immersed into phosphate buffer saline (PBS) solution in a beaker. The beakers with the samples inside were placed in a water bath at $37^{\circ} \mathrm{C}$ for 55 days. The samples were taken off from the water bath and dabbed dry with tissue paper to remove excess water from the surface of the samples. After this, the samples were dried in an oven for $48 \mathrm{~h}$ and reweighed every week. Mass loss of a sample was determined by the following Equation (1):

$$
\operatorname{mass} \operatorname{loss}(\%)=\frac{W_{b}-W_{a}}{W_{b}} \times 100
$$

where $W_{a}$ and $W_{b}$ are weights after and before immersed into distilled water, respectively. 


\subsubsection{Cell Toxicity and Proliferation}

Cell cytotoxicity test was carried out by using MTT (Sigma Aldrich, St. Louis, MO, USA) assay. L-929 cells (fibroblast cell, L929: ECACC, Salisbury, UK) were seeded at $1.5 \times 10^{4}$ in a 48-well plate overnight (total volume $200 \mu \mathrm{L} /$ well). The samples were incubated for one night. MTT solution was added (concentration $5 \mathrm{mg} / \mathrm{mL}$ ) $20 \mu \mathrm{L} /$ well and incubated at $37^{\circ} \mathrm{C}$ for $4 \mathrm{~h}$ in $\mathrm{CO}_{2}$ Incubator. Purple formazan was dissolved using isopropanol with $\mathrm{HCl}$. Measurements were carried out at 540-nm by microplate and the calculation of cell viability is shown in Equation (2).

$$
\text { cell viability }(\%)=\frac{(\text { sample }+ \text { media }+ \text { cell })-(\text { sample }+ \text { media })}{(\text { Media }+ \text { cell })-(\text { sample }+ \text { media })} \times 100 \%
$$

Cell proliferation of L-929 cells (fibroblast cell) were seeded at 5000 cells in 48 -well plates and 3 plates were employed (total volume $200 \mu \mathrm{L} /$ well). The cells were treated with bioactive and the 1st, 2nd and 3rd plate were incubated for $2 \mathrm{~h}, 24 \mathrm{~h}$ and $48 \mathrm{~h}$, respectively. Cell cytotoxicity measurements were recorded. MTT solution was added (concentration $5 \mathrm{mg} / \mathrm{mL}$ ) $20 \mu \mathrm{L} /$ well and incubated at $37^{\circ} \mathrm{C}$ for $4 \mathrm{~h}$ in $\mathrm{CO}_{2}$ incubator. The solution was moved to 96-well plates (100 $\mu \mathrm{L} /$ well). Measurements were carried out using UV light at 540-nm wavelength by a microplate reader [17].

\section{Results and Discussion}

\subsection{Morphologic Analysis of Poly(TT/DPEHA)HIPEs}

3.1.1. The Effect of Surfactant Concentration (Hypermer B246) on Poly(TT/DPEHA)HIPEs Morphology

The obtained poly(TT/DPEHA)HIPEs with the ratio 60:40 of TT/DPEHA monomer and 80\% porosity were characterized by using a scanning electron microscope (SEM) to determine the average pore size and morphology. Poly(TT/DPEHA)HIPEs morphology in Figure 2a-c showed spherical pore, homogenous pore structure with interconnected pore. In order to improve polyHIPEs properties, there are many factors that could affect pore size and interconnected pore and one of these factors is the surfactant concentration. Figure 2 showed the effect of surfactant concentration on the pore size and interconnected pore. Average pore size of poly(TT/DPEHA)HIPEs was analyzed and estimated by measuring the diameter of 50 randomly chosen pores using SemAfore software. SEM micrographs also showed that decreasing amount of Hypermer B246 at $3 \mathrm{wt} \%, 2.7 \mathrm{wt} \%$ and $2.5 \mathrm{wt} \%$ affected the average pore size of the poly(TT/DPEHA)HIPEs, the average pore size increased from $51.2 \pm 9.8 \mu \mathrm{m}$, $103 \pm 10.7 \mu \mathrm{m}$ and $131.4 \pm 26.3 \mu \mathrm{m}$, respectively. This was because of the destabilization of emulsion led to the coalescence of the droplets in the aqueous phase resulted in the larger average pore size [18]. 


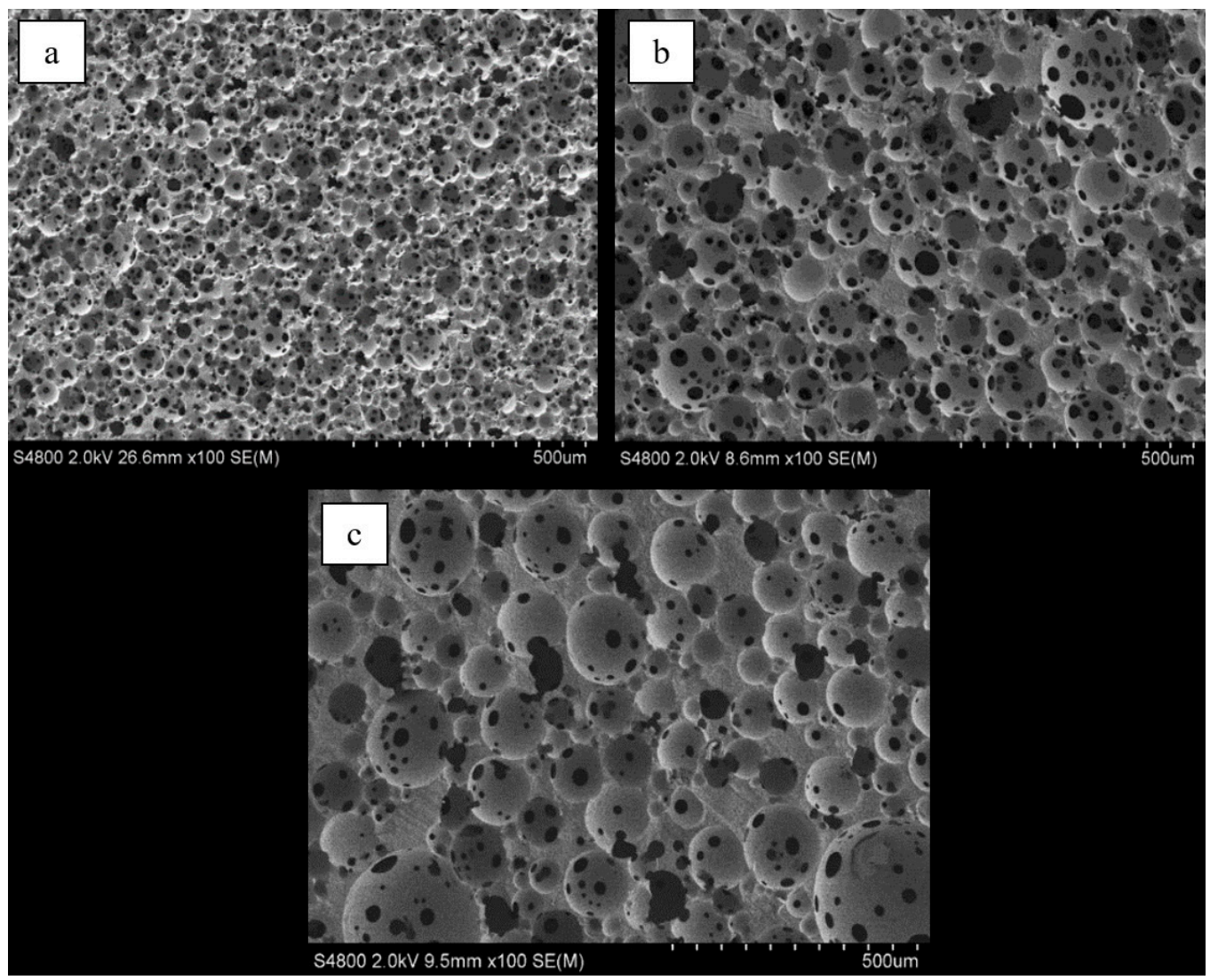

Figure 2. SEM micrographs of poly(TT/DPEHA)HIPEs with different Hypermer B246 concentrations.

(a) $3.0 \mathrm{wt} \%$; (b) $2.7 \mathrm{wt} \%$; (c) $2.5 \mathrm{wt} \%$.

\subsubsection{Effect of Aqueous Phase on Poly(TT/DPEHA)HIPEs Morphology}

The poly(TT/DPEHA)HIPEs were successfully prepared using various amount of aqueous phases ( $80 \mathrm{vol} \%, 90 \mathrm{vol} \%$ and $92 \mathrm{vol} \%$ ) with the same monomer ratios and surfactant concentration at 60:40 and $3 w t \%$, respectively. Morphology of poly(TT/DPEHA)HIPEs in Figure 3(a1-c2) also showed spherical pore, homogenous pore structure with interconnected pore. Average pore size prepared from $80 \mathrm{vol} \%, 90 \mathrm{vol} \%$ and $92 \mathrm{vol} \%$ of aqueous phase were $51.2 \pm 9.8 \mu \mathrm{m}, 63 \pm 14.6 \mu \mathrm{m}$ and $99.9 \pm 27.6 \mu \mathrm{m}$, respectively. These results suggested that at the same amount of surfactant and increased of aqueous phase led to the increased of the average pore size of the polyHIPEs. This was due to the number of surfactant molecules in the emulsion was insufficient to stabilize the increased amount of aqueous phase resulted in a larger droplet hence the larger pores size [19].

This phenomenon related to the Ostwald ripening which explains accordingly about the average droplet sizes and distribution of droplet sizes displayed a growingly uneven trend with the addition of the aqueous phase fraction as all the samples were prepared using the same amount of surfactant, hence the increment of internal phase fraction caused the surplus amount of droplets which were available for the surfactant molecules in the HIPE system thermodynamically driven spontaneous process [18]. The increasing of aqueous phase of polyHIPE from $80 \mathrm{vol} \%$ to $92 \mathrm{vol} \%$, increasing size of water droplets, affected to low stability (or destabilization) of emulsion, water droplets coalescence and Ostwald ripening thus the thickness of walls. On the other hand, the aqueous phase of polyHIPE at $80 \mathrm{vol} \%$ or the high organic: aqueous ratio, small water droplets, low degree of overlapping among voids affected the small size of the interconnected pores [20]. 


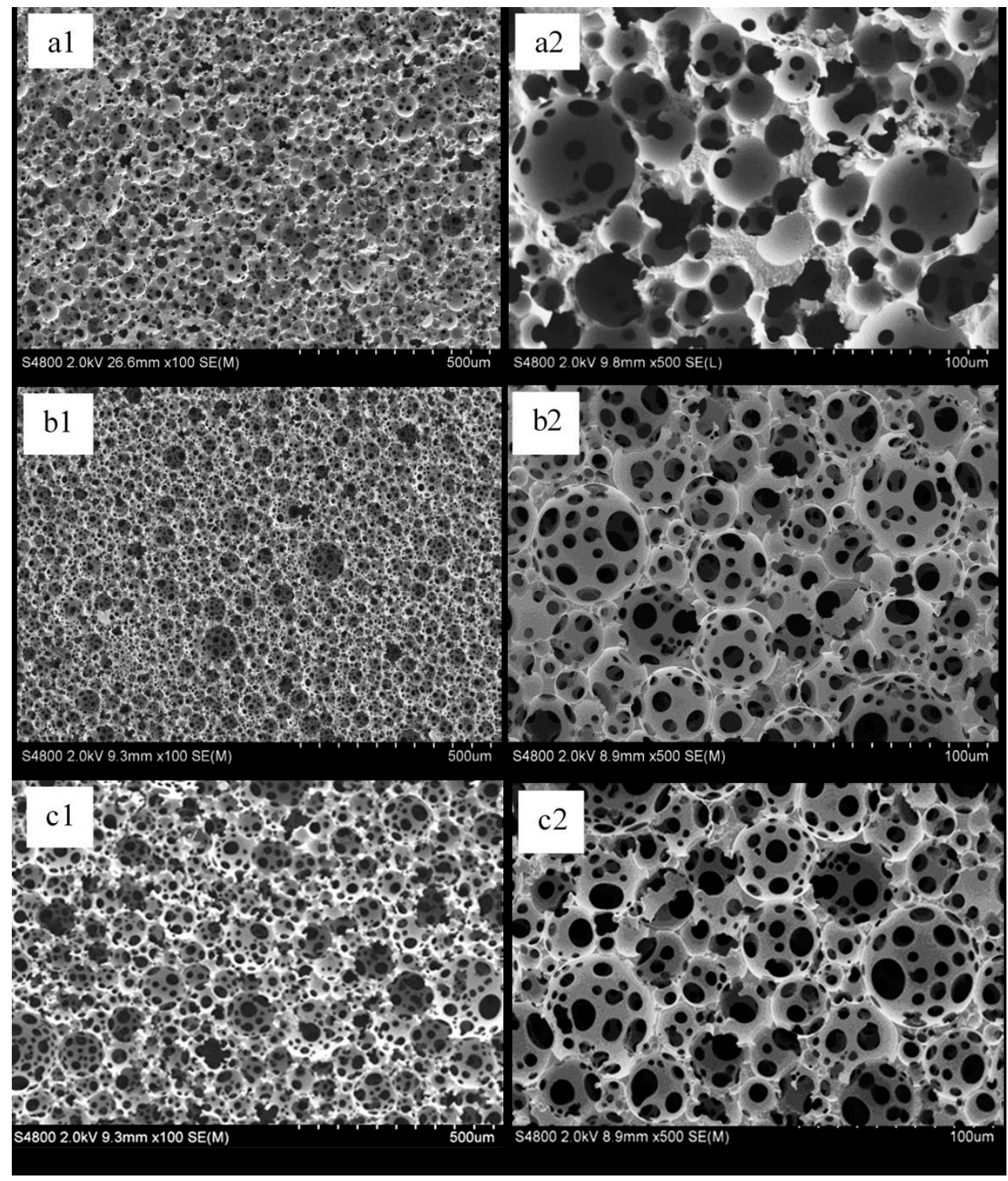

Figure 3. SEM micrographs (100× and 500× magnification) of poly(TT/DPEHA)HIPEs at 3-wt $\%$ Hypermer B246 with different percentages of aqueous phase. (a1,a2) $80 \mathrm{vol} \%$ : (b1,b2) $90 \mathrm{vol} \%$; (c1,c2) $92 \mathrm{vol} \%$.

\subsubsection{Effect of Hydroxyapatite on Poly(TT/DPEHA)HIPEs Morphology}

Poly(TT/DPEHA/HA)HIPEs filled with hydroxyapatite (HA) were successfully prepared. The amount of HA added to poly(TT/DPEHA/HA)HIPEs resulted in a non-homogeneous pore structure or the pore size distribution and the pores were randomly distributed (See Figure 4(a1-d2)). As the amount of HA increased up to $5 \mathrm{wt} \%$, pore sizes of poly(TT/DPEHA/HA)HIPEs were increased from $99.9 \pm 27.6 \mu \mathrm{m}$ to $107.78 \pm 57.4 \mu \mathrm{m}$ as shown in Figure $4(\mathrm{~b} 1, \mathrm{~b} 2)$ because of the destabilization of emulsion [21]. Moreover, the increase amount of hydroxyapatite gave a larger pore size, rough surface and more distinctly interconnected pores which could affect cellular infiltration in scaffolds [22]. As the amount of HA increased to more than $5 \mathrm{wt} \%$, poly(TT/DPEHA/HA)HIPEs showed nonhomogeneous dispersions of aqueous phase caused by high viscosity of the emulsion. In addition, with the increment amount of HA, leading to the high shear stress of mixing, emulsion was unable to break up the large droplets. It means that by lowering the concentration of HA to a certain level, coalescence would decrease between droplets of the emulsion which ultimately would obstruct the size that they grow to and resulted in smaller size pores [23]. On the other hand, heightening amount of HA caused 
abundance of phosphorus and calcium clots covered on surface of the polyHIPEs and led to local stress on the sample.

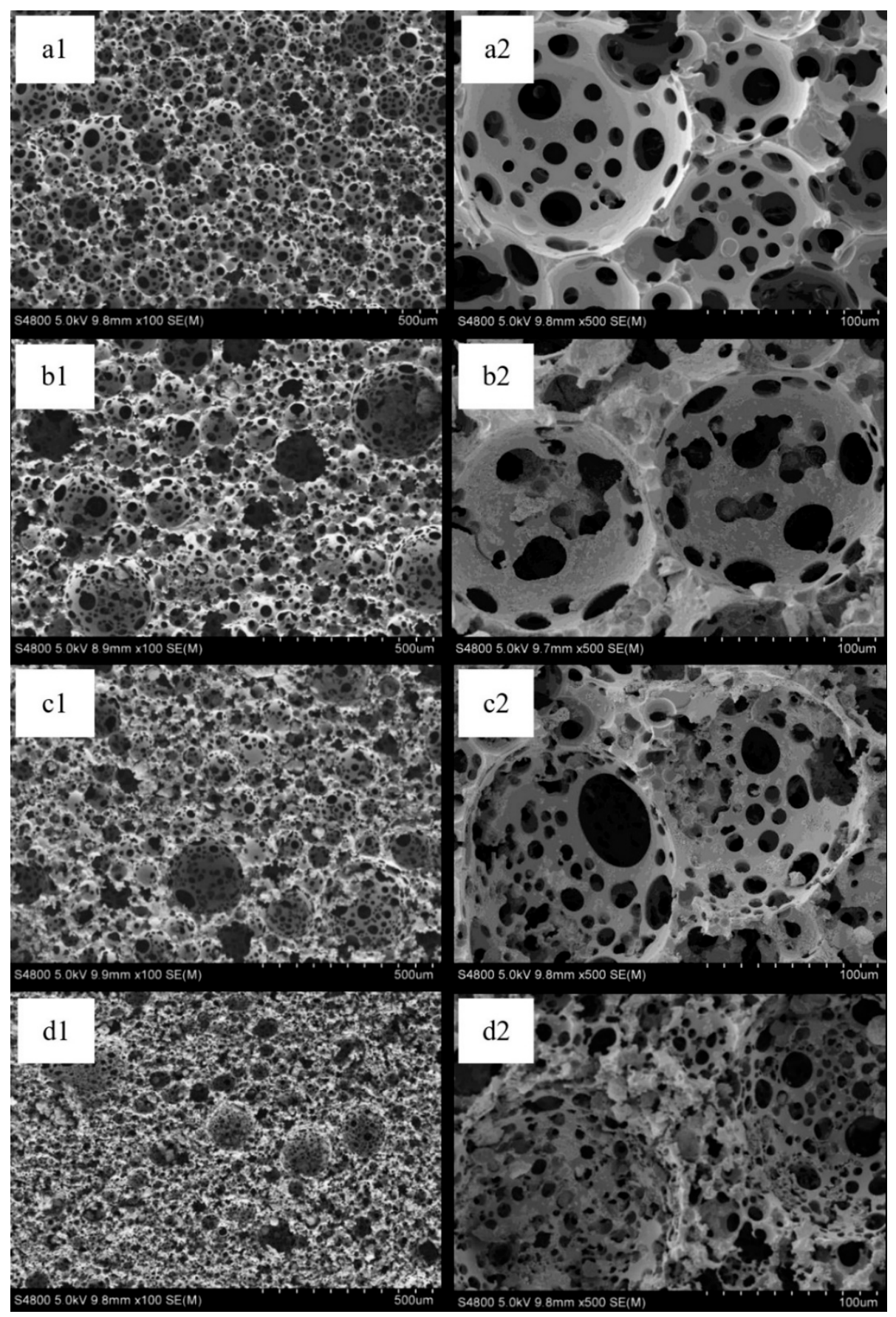

Figure 4. SEM micrographs (100× and 500× magnification) of poly(TT/DPEHA/HA)HIPEs. (a1,a2) PolyHIPEs without HA; (b1,b2) 5-HA HIPEs; (c1,c2) 10-HA HIPEs; (d1,d2) 15-HA HIPEs at $92 \mathrm{vol} \%$ aqueous phase.

\subsubsection{Distribution of HA in Poly(TT/DPEHA/HA) HIPEs}

Scanning electron microscopy (SEM) and energy dispersive X-ray analysis (EDX) were used to identify the dispersion and the distribution of the HA added to poly(TT/DPEHA/HA)HIPEs. HA is a calcium phosphate compound which has calcium and phosphorus as the major compositional elements. The distribution of the elements from the hydroxyapatite on the surface of poly(TT/DPEHA/HA)HIPEs 
is shown in Figure 5a-d. The distribution of HA demonstrated a very good homogeneity on poly(TT/DPEHA/HA)HIPEs surface.

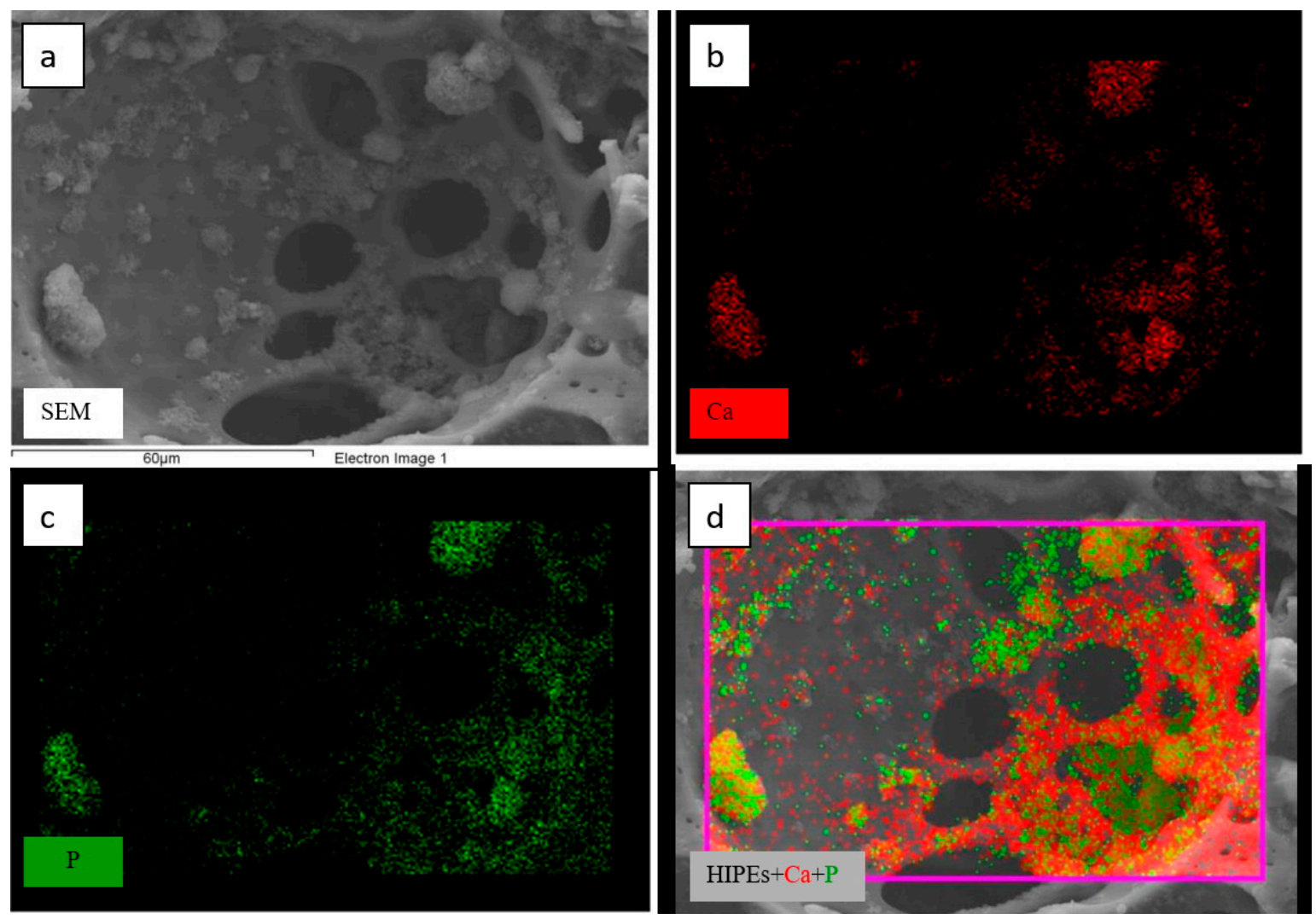

Figure 5. EDX mapping of poly(TT/DPEHA/HA)HIPEs containing 5-wt $\%$ hydroxyapatite. (a) SEM image of scanned region, (b) area map highlighting the presence of calcium shown in red, (c) area map highlighting the presence of phosphorus shown in green, (d) overlay map of calcium and phosphorus.

\subsection{Chemical Analysis}

\subsubsection{FTIR-ATR Analysis}

Figure 6a-e shows FTIR-ATR spectra of poly(TT/DPEHA/HA)HIPEs with different amount of hydroxyapatite. The spectra were collected between $4000-600 \mathrm{~cm}^{-1}$. FTIR spectrum of HA shown sharp peaks appeared at $1020 \mathrm{~cm}^{-1}$ indicating the presence of phosphate $\mathrm{PO}_{4}^{3-}$ from $\mathrm{HA}$ which corresponded to the phosphate moiety [24]. Poly(TT/DPEHA/HA)HIPEs spectra also show a sharp peaks at $1730 \mathrm{~cm}^{-1}$ corresponded to the $\mathrm{C}=\mathrm{O}$ stretching and $1100 \mathrm{~cm}^{-1}$ which is corresponded to $\mathrm{C}-\mathrm{O}$ bond peak stretching and $\mathrm{C}-\mathrm{H}$ stretching at $2853 \mathrm{~cm}^{-1}$ transmittance [25]. When comparing between spectra of poly(TT/DPEHA)HIPEs with spectra from poly(TT/DPEHA/HA)HIPEs the presence of phosphate at $1020 \mathrm{~cm}^{-1}$ wavelength were clearly observed in poly(TT/DPEHA/HA)HIPEs and not in poly(TT/DPEHA)HIPEs spectra. 


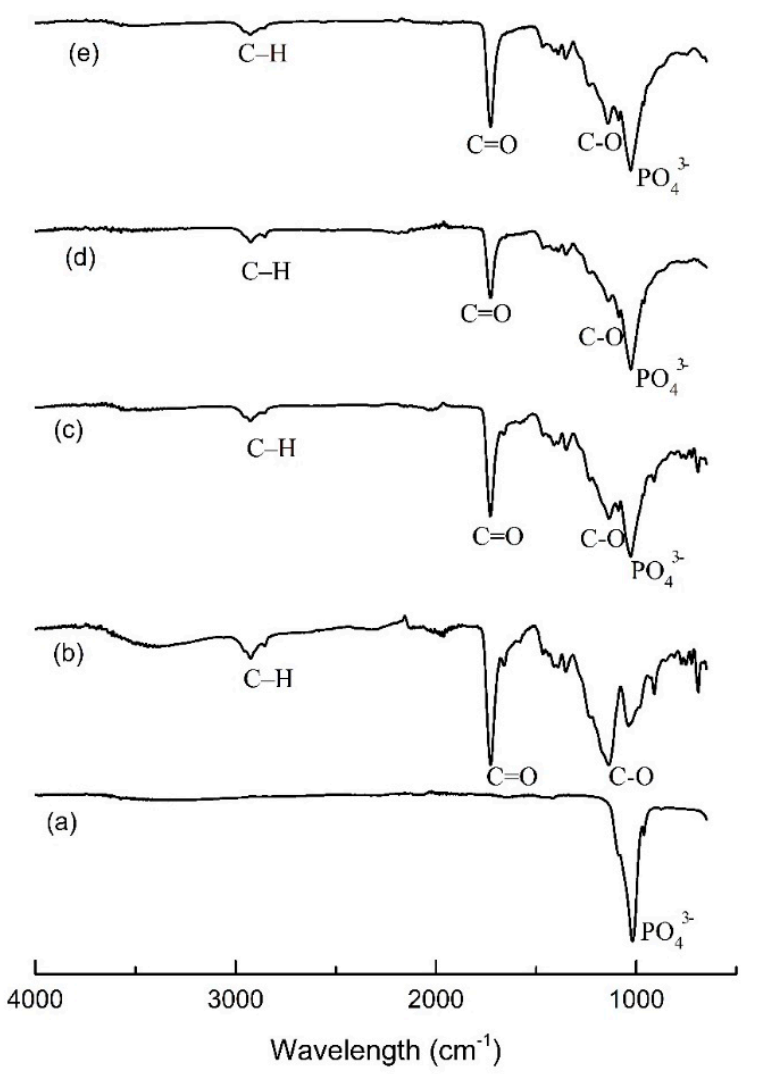

Figure 6. FTIR spectra. (a) Hydroxyapatite (HA); (b) Poly(TT/DPEHA)HIPEs; (c) 5-HA HIPEs; (d) 10-HA HIPEs; (e) 15-HA HIPEs.

\subsubsection{Thermogravimetric Analysis}

Thermogravimetric analysis or TGA was used to analyze the decomposition temperature of poly(TT/DPEHA/HA)HIPEs and confirmed the presence of HA particles in the polyHIPEs. The results showed facile conclusion about negative decomposition of HA within the range of thermal testing as shown accordingly. For the polyHIPEs with different amount of HA, the results illustrated that the polymer degraded approximately within the range of temperature between $300-460^{\circ} \mathrm{C}$. In comparison between poly(TT/DPEHA)HIPEs and poly(TT/DPEHA/HA)HIPEs, the results revealed that poly(TT/DPEHA)HIPEs showed a higher onset temperature compared to the poly(TT/DPEHA/HA)HIPEs (see Table 1 and Figure 7). The polymer degradation started between 330-322 ${ }^{\circ} \mathrm{C}$ because HA particles embedded in the polymer matrix were non-homogenous which influenced the onset to be slightly different [26]. Table 1 also shows that the decomposition of polyHIPEs gradually decreased as increasing of HA weight percentage between $0-15 \mathrm{wt} \%$ at $94.21 \%, 90.31 \%$, $84.22 \%$ and $77.15 \%$. From the decomposition results, it could be concluded that increasing of HA weight percent in the polyHIPEs led to the high amount of unscathed residues as the polyHIPEs were composed of organic and inorganic compounds [27].

Table 1. Thermal properties of poly(TT/DPEHA/HA)HIPEs by thermogravimetric analysis.

\begin{tabular}{ccc}
\hline Sample & $\mathbf{T}_{\mathbf{d}}$ Onset $\left({ }^{\circ} \mathbf{C}\right)$ & Mass Loss $(\mathbf{\%})$ \\
\hline PolyHIPEs & 330 & 94.21 \\
5-HA HIPEs & 325 & 90.31 \\
10-HA HIPEs & 322 & 84.22 \\
15-HA HIPEs & 322 & 77.15 \\
\hline
\end{tabular}




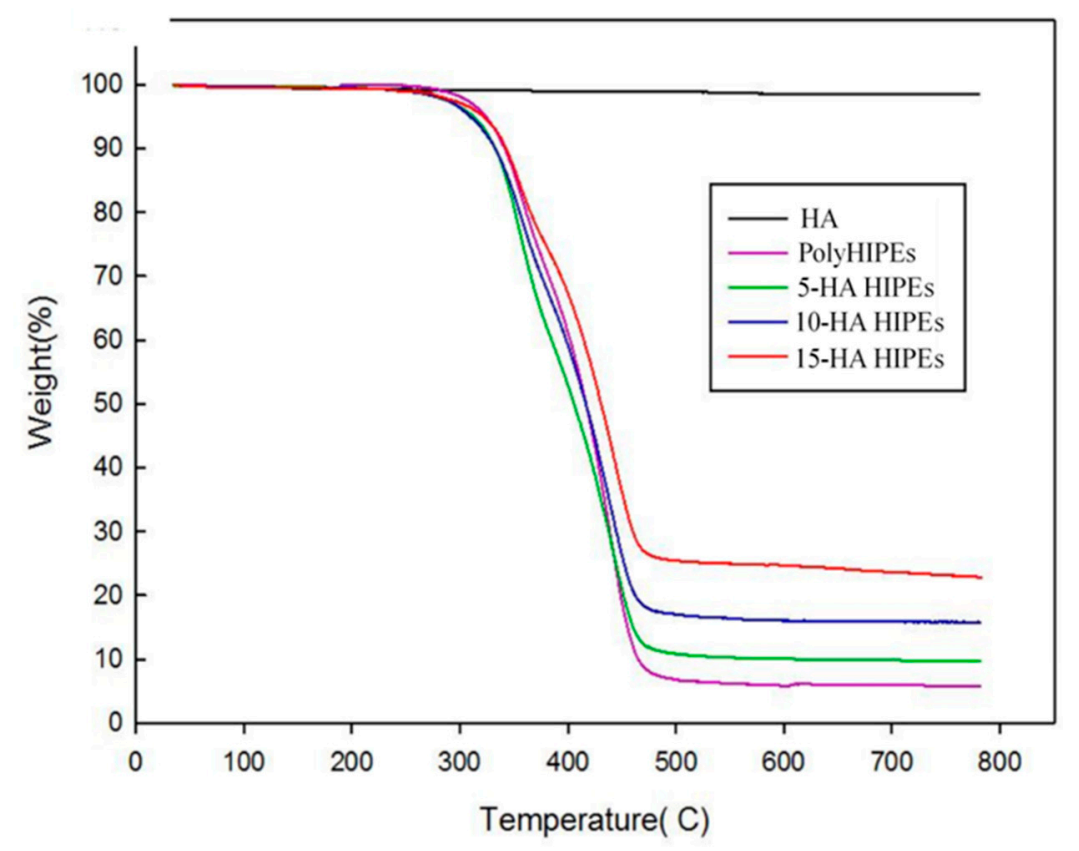

Figure 7. TGA curve of poly(TT/DPEHA)HIPEs with various amount of HA.

\subsection{Mechanical Properties Test}

\subsubsection{Degradation Test}

Currently, various methodologies have been developed to prepare biodegradable porous polymeric materials. A large number of researchers predesigned greener templates which at least avoided the use of hazardous inorganic material or poisonous solvents [28,29]. Figure 8 revealed the percentage mass loss (\%) and days taken to degrade towards different volume percentage of the aqueous phase of poly(TT/DPEHA)HIPEs. The plot illustrated the increased degradation in 55-day period, which explains that the effect of hydrolytic degradation has been taken place in those period. Moreover, poly(TT/DPEHA)HIPEs with $90 \mathrm{vol} \%$ aqueous phase displayed the higher percentage of mass loss $(\%)$ due to the higher amount of porosity and the larger surface area which enhanced the degradation of the sample. In biodegradable poly(TT/DPEHA)HIPEs with lower surface area, they tended not to breakdown easily and did not experienced any rapid degradation [29]. In tissue engineering application, it was suggested that biodegradable materials used in the application needed to maintain their integrity from degradation during the bone regenerating periods so that they can optimize the rejuvenation of the treated bone and then gradually degrade as needed [29]. In this respect, it explains why the degradation of the sample must be slow and consistence throughout the material. Cells need more time to generate while adapt with the co-culture environment, so it may be explained the need for poly(TT/DPEHA/HA)HIPEs with the moderate rate of degradation. The degradation test of poly(TT/DPEHA/HA)HIPEs showed the slow mass loss rate and the maximum mass loss at $7 \%$ was suitable for the scaffolds application as stated by Christopher and coworker whose research on the evaluation of polycaprolactone scaffold degradation required gentle and late mass loss combined with long term biocompatibility and bone regeneration [30]. 


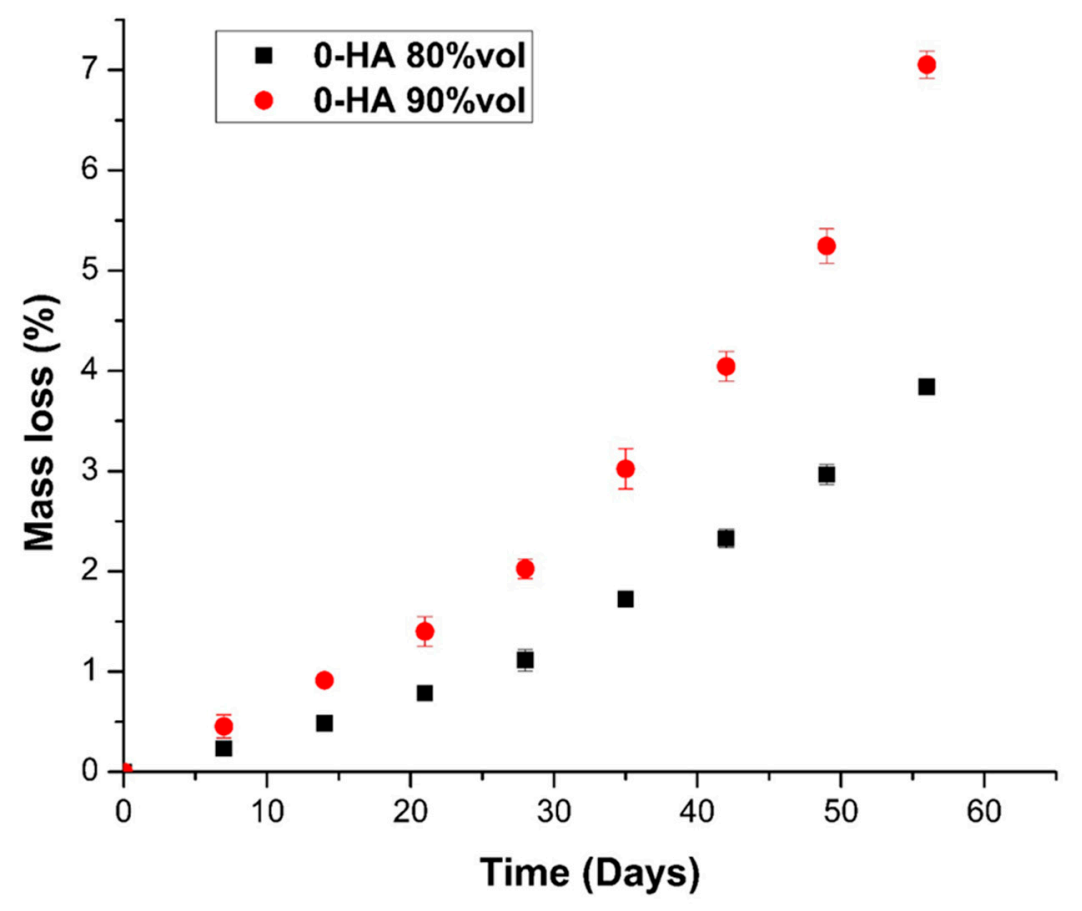

Figure 8. Degradation of poly(TT/DPEHA)HIPEs with 80 and $90 \%$ by volume of aqueous for 55 days.

\subsubsection{Compression Test}

One of the important properties of polyHIPEs for tissue engineering is the ability to withstand force without breaking. The mechanical property of porous poly(TT/DPEHA)HIPEs were determined by stress/strain curves (see Figure 9). All the poly(TT/DPEHA)HIPEs exhibited uniaxial tensile stress-strain profiles were classified as ductile materials [31]. Table 2 shows that mechanical properties the poly(TT/DPEHA/HA)HIPEs enhanced with hydroxyapatite were able to withstand compressive modulus between 4.8-6.2 MPa which is suitable for supporting mandible trabecular bones. From the earlier research, it was stated that trabecular bone ultimate compressive strength range is from 0.22 to $10.44 \mathrm{MPa}$. Meanwhile, the suitable young's modulus mean value range from 3.9-199.5 MPa depending on the bone types. It was observed that the stress at maximum load and compressive modulus were significantly enhanced with the increasing of HA up to $5 \mathrm{wt} \%$ due to the reinforcement induced by the inclusion of HA into polyHIPEs [21,32]. Conversely, excessive amount of HA particles $(>5 \mathrm{wt} \%$ ) showed decreasing both the stress at maximum load and the compressive modulus. This may due to two main factors, one factor was agglomeration of HA creating the weak point in porous structure [33] and another one was the larger pore size led to the lower stress transfer [34].

Table 2. Mechanical properties of poly(TT/DPEHA/HA)HIPEs under compression.

\begin{tabular}{ccc}
\hline Sample & Stress at Maximum Load (MPa) & Compressive Modulus (MPa) \\
\hline PolyHIPEs & $1.05 \pm 0.22$ & $5.82 \pm 1.06$ \\
5-HA HIPEs & $1.24 \pm 0.11$ & $6.17 \pm 0.74$ \\
10-HA HIPEs & $0.90 \pm 0.17$ & $5.07 \pm 1.00$ \\
15-HA HIPEs & $0.60 \pm 0.14$ & $4.84 \pm 0.84$ \\
\hline
\end{tabular}




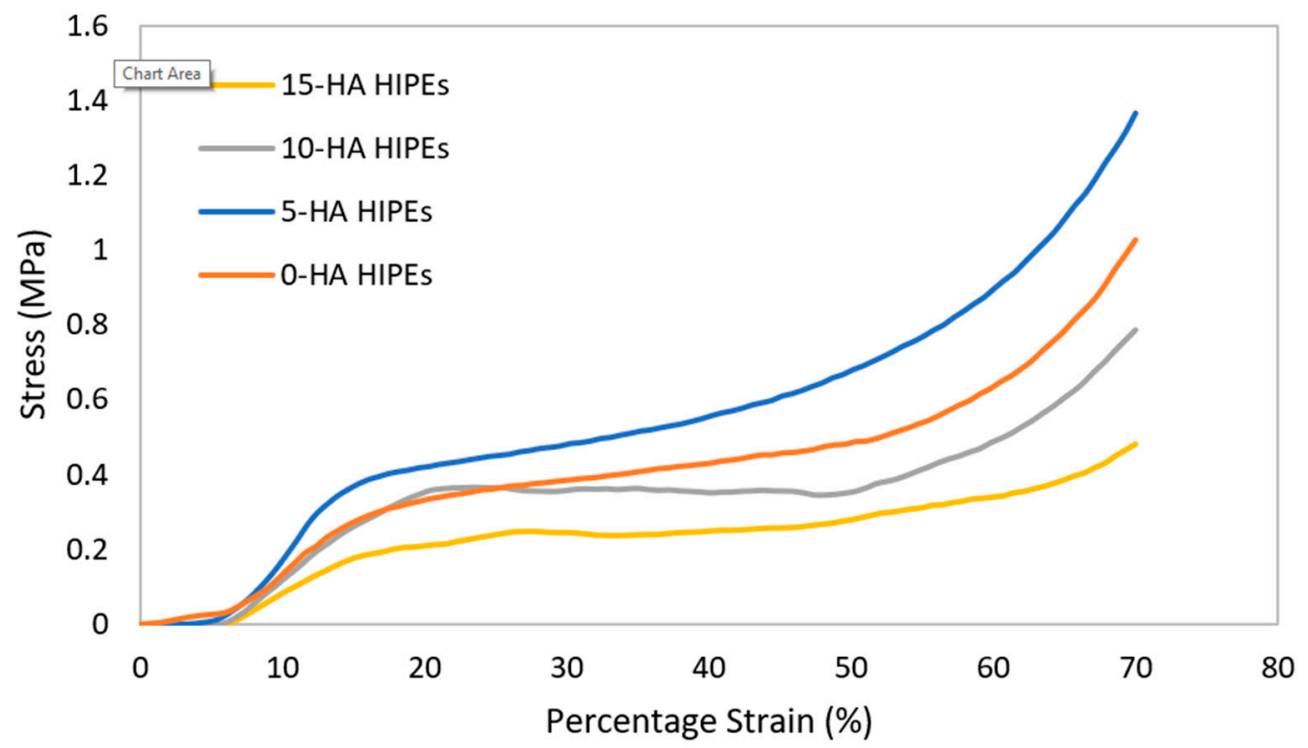

Figure 9. Stress-strain curve of poly(TT/DPEHA)HIPEs with various amount of HA.

\subsection{Biologic Test}

\subsubsection{Cell Cytotoxicity by Using MTT Assay}

Result in Figure 10 shows progressive cell growth for both poly(TT/DPEHA)HIPEs with different amount of HA. After $24 \mathrm{~h}$, poly(TT/DPEHA)HIPE with $0 \%$ of HA and poly(TT/DPEHA/HA)HIPE with $5 \%$ of HA showed a significantly difference in cell growth when compared with the control. The control sample showed $100 \%$ of cell growth while a substantial growth of the L-929 cell up to $180 \%$ were observed in the other samples. The 0-HA and 5-HA poly(TT/DPEHA/HA)HIPEs depicted an accumulation of 153.9 and $176.59 \%$ of cell growth, respectively. From the result, it was indicated a promising result of negatively cytotoxicity of poly(TT/DPEHA/HA)HIPEs with or without HA in direct contact of the fibroblast cells (L-929) cultures. The results supported the claimed of thiol-ene polymerization material especially, poly(TT/DPEHA/HA)HIPEs were nontoxic and could be improved and developed for the biomedical scaffold application. Furthermore, the incorporation of HA into the poly(TT/DPEHA/HA)HIPEs were believed to increase the cell viability because it managed to upsurge the surface roughness on poly(TT/DPEHA/HA)HIPEs sample thus enhanced the ability of the cell attachment and favored more cell growth on its surface.

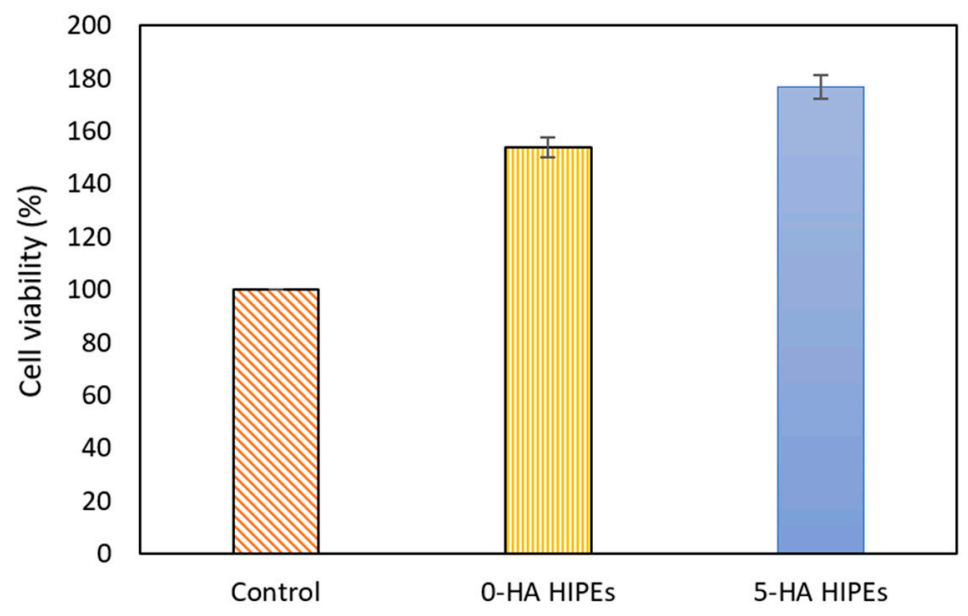

Figure 10. Cell viability assay (MMT) of mouse fibroblast cells (L-929) with different amount of HA on poly(TT/DPEHA)HIPEs for $24 \mathrm{~h}$. 


\subsubsection{Cell Proliferation by Using MTT Assay}

Typically, the L-929 cells are approximately 5-10 $\mu \mathrm{m}$. Where the average pore size of poly(TT/DPEHA)HIPEs with 0 -HA was $99.9 \pm 27.6 \mu \mathrm{m}$ and 5 -HA was $107.78 \pm 57.4 \mu \mathrm{m}$. The L-929 cells were able to penetrate though the pores and the interconnected pores of poly(TT/DPEHA)HIPEs. In this test, the effect of HA on the cell proliferation could be determined by MTT assay. In the bioanalysis of cell proliferation test, usually the fibroblast will first come in contact with the surface of culture media and they will incessantly attach, adhere and spread on it. The L-929 fibroblast cells were extracted from the cell grown on polyHIPEs samples and were continued to feed in medium at 24 and $48 \mathrm{~h}$. Figure 11 shows the results of cell proliferation in poly(TT/DPEHA)HIPEs with different amount of HA within 24 and $48 \mathrm{~h}$ period. In $24 \mathrm{~h}$, cell proliferation were recorded, 0-HA of poly(TT/DPEHA)HIPE disclosed the cell proliferation of $0.90 \pm 0.06$ in $24 \mathrm{~h}$ and $0.86 \pm 0.06$ in $48 \mathrm{~h}$. In contrast, poly(TT/DPEHA)HIPEs with $5 \%$ of HA showed constructive cell growth with cell proliferation at $1.10 \pm 0.00$ and increased after $48 \mathrm{~h}$ to $2.12 \pm 0.21$.

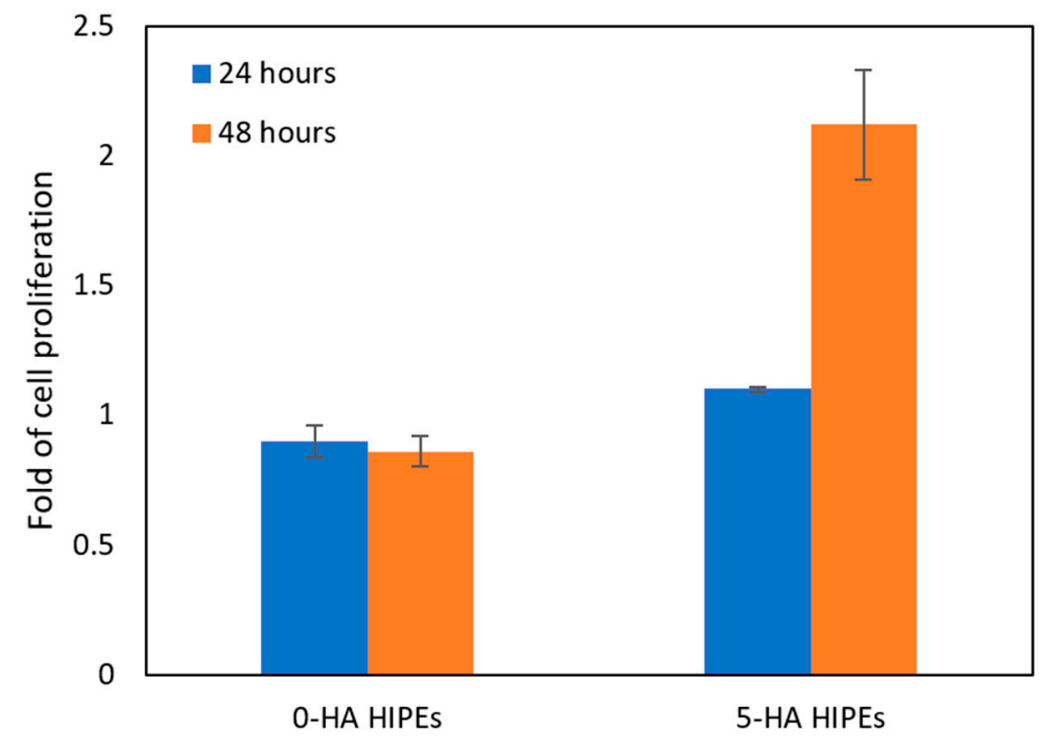

Figure 11. Cell proliferation of L-929 by MTT assay in 24 and $48 \mathrm{~h}$ with different amount of HA in poly(TT/DPEHA/HA) HIPEs.

Nevertheless, chemical nature and topography of the materials used for the development of cell in this study favored cell-material interactions (See Figure 12(a1-b3)). The abundancy of open cell fabricated in poly(TT/DPEHA/HA)HIPEs sample body were able to increase the cell growth. This can be attributed to the nanodimensions of the HA as well as the compatibility for both the HA and poly(TT/DPEHA)HIPEs. These behaviors helped to correlate protein adsorption and contributed for the cellular adhesion [35]. The incorporation of 5-HA in poly(TT/DPEHA)HIPEs really benefits for L-929 cell proliferation as shown in Figure 12(b3). It shows the changed of fibroblast cell shape from round-like and flattened Figure 12(b1) to more elongated spindle-like shaped cells. In addition, Figure 12(b3) possessing extending out from the ends of the cell body. 


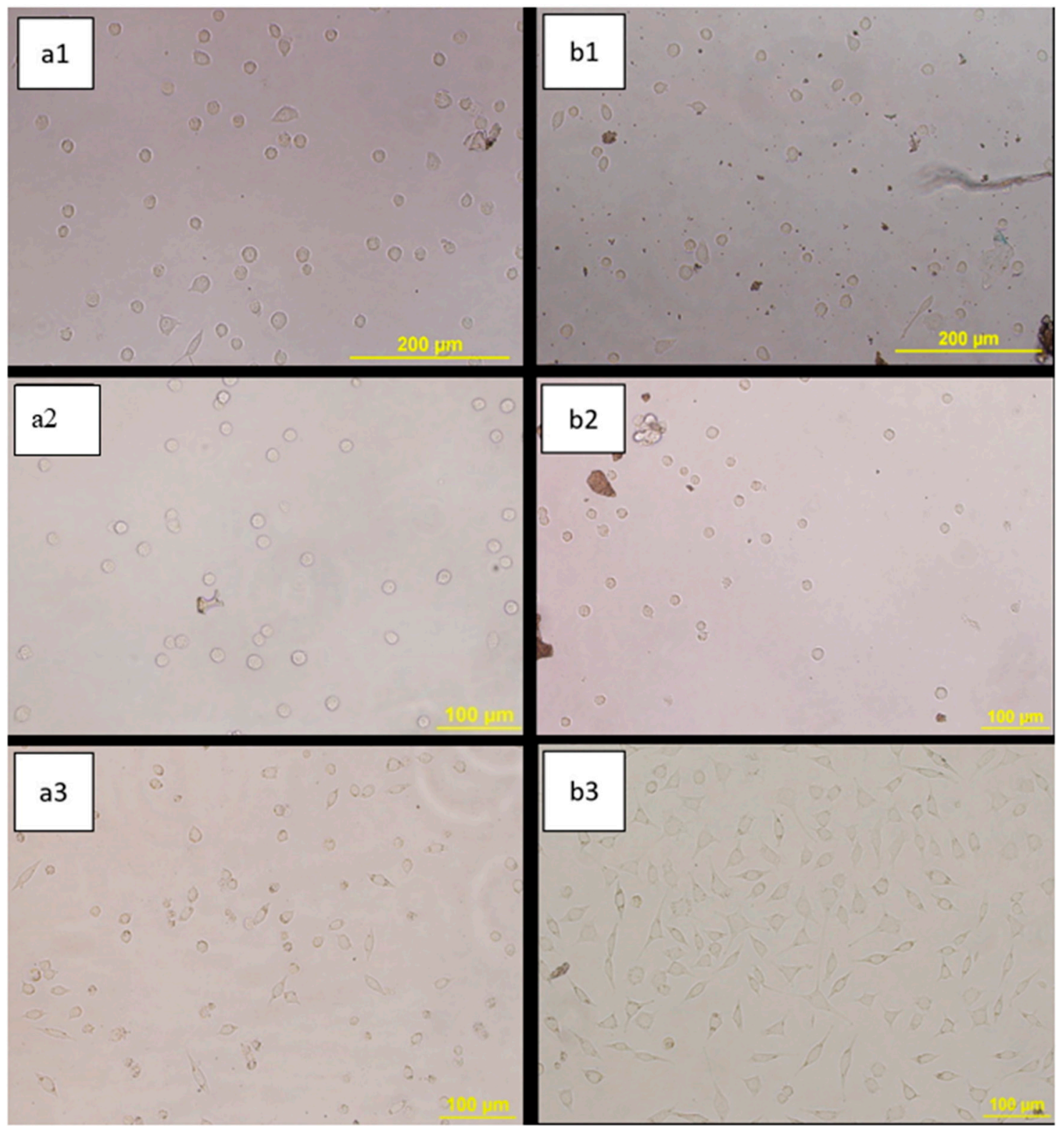

Figure 12. Optical micrographs. (a1) L-929 in 0-HA at 0 h; (a2) L-929 in 0-HA at 24 h; (a3) L-929 in 0-HA at 48 h; (b1) L-929 in 5-HA HIPEs at 0 h; (b2) L-929 in 5-HA HIPEs at 24 h; (b3) L-929 in 5-HA HIPEs at $48 \mathrm{~h}$.

The applications of porous HA are wildly used in the biomedical field. Moreover, they have been used for the hard tissue scaffolding, cell loading and drug releasing agents. The experiment was set up in order to distinguish the effect of the polyHIPEs enhanced with content of HA towards the adhesion/proliferation rate of the cells. Generally, for the tissue engineering, porous HA scaffold were used as filling materials for bone defects and augmentation, artificial bone graft material and prosthesis revision surgery. Its high surface area and porosity led to excellent cell conductivity and reabsorption ability favored for fast cell in growth [36]. It shows the cell proliferation result of the poly(TT/DPEHA/HA)HIPEs. From the data presented it resembled an excellent cell growth as shown accordingly. 


\section{Conclusions}

This study systematically examined thiol-ene-based polymers as the raw material by polymerizing an aqueous in oil phase of high-internal-phase-emulsion (HIPEs) and a series of porous materials were prepared. Although polymerization of thiol-ene groups monomers such as DPEHA and TT has been reported in the past, but in this study, exclusively focused on the incorporation of different concentrations of alpha hydroxyapatite (HA) towards poly(TT/DPEHA)HIPEs for cell proliferation application was carry out. The first stage of this research emphasizes the use of Hypermer B246 as the conventional surfactant for poly(TT/DPEHA/HA)HIPEs stabilization. Moreover, we succeed on fabricated a high-porosity thiol-ene polymer foams with tunable morphology (open pores). The investigation furthered by investigating the concentrations of surfactant, amount of crosslinker and the aqueous phase volume. The studies were broadened by demonstrating the inclusions of HA nanoparticle for the biologic application. The content of the formulation gave significant effects on the morphology of the poly(TT/DPEHA/HA)HIPEs formed with a relatively high particle loading negatively affecting the stability of the emulsion and also increase the mechanical strength. Poly(TT/DPEHA/HA)HIPEs with $5 \%$ of HA portrayed a very promising cell proliferation towards the fibroblast (L-929) cell with total cell proliferation up to 2.12. From the results, it could be concluded that the finest ratios of the poly(TT/DPEHA/HA)HIPEs Hypermer B246 with 5\% HA. Further work was strategically planned for tailoring polyHIPEs template using other source of radiation which could use less energy and reduce polymerization time and thus shorten the preparation time.

Author Contributions: Conceptualization, M.I.A., N.K., J.P., M.N., and P.S.; methodology, M.I.A., N.K., J.P., M.N., and P.S.; formal analysis, M.I.A., N.K., J.P., M.N., and P.S.; investigation, M.I.A., N.K., J.P., M.N., and P.S.; data curation, M.I.A., N.K., J.P., M.N., and P.S.; writing-original draft preparation, M.I.A., N.K., J.P., M.N., and P.S.; writing-review and editing, M.I.A., N.K., J.P., M.N., and P.S.; visualization, M.I.A., N.K., J.P., M.N., and P.S.; supervision, M.N.; project administration, P.S. and M.N.; funding acquisition, M.I.A. and M.N. All authors have read and agreed to the published version of the manuscript.

Funding: This research was funded by ASEAN scholarship, Chulalongkorn University.

Acknowledgments: The authors were supported by the ASEAN scholarship, Chulalongkorn University.

Conflicts of Interest: The authors declare that this work is original and has not been published elsewhere nor is it currently under consideration for publication elsewhere. All authors have approved the manuscript and agree with its submission to this journal.

Compliance of Ethics: We declare this article does not contain any studies with human or animal subject laws and were follows the compliance of ethics to disclose.

\section{References}

1. Myers, D. Surfaces, Interfaces, and Colloids; Wiley-Vch New York etc.: Hoboken, NJ, USA, 1999; Volume 358.

2. Silverstein, M.S. Emulsion-templated porous polymers: A retrospective perspective. Polymer 2014, 55, 304-320. [CrossRef]

3. Cameron, N.; Sherrington, D. High internal phase emulsions (HIPEs)—Structure, properties and use in polymer preparation. In Biopolymers Liquid Crystalline Polymers Phase Emulsion; Springer: Berlin, Germany, 1996; pp. 163-214.

4. Zhang, H.; Cooper, A.; Zhang, H.; Cooper, A.I. Synthesis and applications of emulsion-templated porous materials. Soft Matter 2005, 1, 107-113. [CrossRef] [PubMed]

5. Caldwell, S.; Johnson, D.W.; Didsbury, M.P.; Murray, B.A.; Wu, J.J.; Przyborski, S.A.; Cameron, N.R. Degradable emulsion-templated scaffolds for tissue engineering from thiol-ene photopolymerisation. Soft Matter 2012, 8, 10344-10351. [CrossRef]

6. Torstrick, F.B.; Evans, N.T.; Stevens, H.Y.; Gall, K.; Guldberg, R.E. Do surface porosity and pore size influence mechanical properties and cellular response to PEEK? Clin. Orthop. Relat. Res. 2016, 474, $2373-2383$. [CrossRef] [PubMed]

7. Torres-Sanchez, C.; Al Mushref, F.; Norrito, M.; Yendall, K.; Liu, Y.; Conway, P.P. The effect of pore size and porosity on mechanical properties and biological response of porous titanium scaffolds. Mater. Sci. Eng. C 2017, 77, 219-228. [CrossRef] 
8. Pakeyangkoon, P.; Magaraphan, R.; Malakul, P.; Nithitanakul, M. Effect of soxhlet extraction and surfactant system on morphology and properties of poly (DVB) polyHIPE. In Macromolecular Symposia; Wiley-VCH Verlag: Weinheim, Germany, 2008; pp. 149-156.

9. Wu, D.; Xu, F.; Sun, B.; Fu, R.; He, H.; Matyjaszewski, K. Design and preparation of porous polymers. Chem. Rev. 2012, 112, 3959-4015. [CrossRef]

10. Lovelady, E.; Kimmins, S.D.; Wu, J.; Cameron, N.R. Preparation of emulsion-templated porous polymers using thiol-ene and thiol-yne chemistry. Polym. Chem. 2011, 2, 559-562. [CrossRef]

11. Chen, C.; Eissa, A.M.; Schiller, T.L.; Cameron, N.R. Emulsion-templated porous polymers prepared by thiol-ene and thiol-yne photopolymerisation using multifunctional acrylate and non-acrylate monomers. Polymer 2017, 126, 395-401. [CrossRef]

12. Harikrishna, R.; Shaikh, A.; Ponrathnam, S.; Rajan, C.; Bhongale, S. Photopolymerization of high internal phase emulsions based on 2-ethylhexyl (meth) acrylates and ethylene glycol dimethacrylate. Des. Monomers Polym. 2014, 17, 1-6. [CrossRef]

13. Sopyan, I.; Mel, M.; Ramesh, S.; Khalid, K. Porous hydroxyapatite for artificial bone applications. Sci. Technol. Adv. Mater. 2007, 8, 116. [CrossRef]

14. Galindo, T.G.P.; Chai, Y.; Tagaya, M. Hydroxyapatite nanoparticle coating on polymer for constructing effective biointeractive interfaces. J. Nanomater. 2019, 2019, 6495239. [CrossRef]

15. Sharma, A.; Molla, M.S.; Katti, K.S.; Katti, D.R. Multiscale models of degradation and healing of bone tissue engineering nanocomposite scaffolds. J. Nanomech. Micromech. 2017, 7, 04017015. [CrossRef]

16. Wei, G.; Ma, P.X. Structure and properties of nano-hydroxyapatite/polymer composite scaffolds for bone tissue engineering. Biomaterials 2004, 25, 4749-4757. [CrossRef] [PubMed]

17. Ciapetti, G.; Cenni, E.; Pratelli, L.; Pizzoferrato, A. In vitro evaluation of cell/biomaterial interaction by MTT assay. Biomaterials 1993, 14, 359-364. [CrossRef]

18. Wan, X.; Azhar, U.; Wang, Y.; Chen, J.; Xu, A.; Zhang, S.; Geng, B. Highly porous and chemical resistive $\mathrm{P}$ (TFEMA-DVB) monolith with tunable morphology for rapid oil/water separation. RSC Adv. 2018, 8, 8355-8364. [CrossRef]

19. Preechawong, J.; Chindacharin, S.; Sapsrithong, P.; Nithitanakul, M. Mesoporous water adsorbent material from poly high internal phase emulsion for agriculture application. J. Appl. Polym. Sci. 2017, 134, 45509. [CrossRef]

20. Barbetta, A.; Cameron, N.R. Morphology and Surface Area of Emulsion-Derived (PolyHIPE) Solid Foams Prepared with Oil-Phase Soluble Porogenic Solvents: Span 80 as Surfactant. Macromolecules 2004, 37, 3188-3201. [CrossRef]

21. Lee, A.; Langford, C.R.; Rodriguez-Lorenzo, L.M.; Thissen, H.; Cameron, N.R. Bioceramic nanocomposite thiol-acrylate polyHIPE scaffolds for enhanced osteoblastic cell culture in 3D. Biomater. Sci. 2017, 5, 2035-2047. [CrossRef]

22. Murphy, C.M.; Haugh, M.G.; O'brien, F.J. The effect of mean pore size on cell attachment, proliferation and migration in collagen-glycosaminoglycan scaffolds for bone tissue engineering. Biomaterials 2010, 31, 461-466. [CrossRef]

23. Berber, E.; Çira, F.; Mert, E.H. Preparation of porous polyester composites via emulsion templating: Investigation of the morphological, mechanical, and thermal properties. Polym. Compos. 2016, 37, 1531-1538. [CrossRef]

24. Shavandi, A.; Bekhit, A.E.-D.A.; Ali, A.; Sun, Z. Synthesis of nano-hydroxyapatite (nHA) from waste mussel shells using a rapid microwave method. Mater. Chem. Phys. 2015, 149, 607-616. [CrossRef]

25. Harun, N.A.; Kassim, S.; Muhammad, S.T.; Rohi, F.E.; Norzam, N.N.; Tahier, N.S.M. The effect of nonionic surfactants on emulsion polymerization of poly (methacrylic acid) nanoparticles. In Proceedings of the 3rd Electronic and Green Materials International Conference 2017, Aonang Krabi, Thailand, 29-30 April 2017; p. 020032.

26. Persson, M.; Cho, S.-W.; Berglin, L.; Tuukkanen, J.; Skrifvars, M. Poly (Lactid Acid)/Hydroxipatite Composite Fibres for 3D Osteoconductive Woven Scaffolds. In Proceedings of the ECCM15 15th European Conference on Composite Materials, Venice, Italy, 24-28 June 2012.

27. Chakraborty, S.; Roy, P.; Pathak, A.; Debnath, M.; Dasgupta, S.; Mukhopadhyay, R.; Bandyopadhyay, S. Composition analysis of carbon black-filled polychloroprene rubber compound by thermo-oxidative degradation of the compound. J. Elastom. Plast. 2011, 43, 499-508. [CrossRef] 
28. Yang, X.-Y.; Chen, L.-H.; Li, Y.; Rooke, J.C.; Sanchez, C.; Su, B.-L. Hierarchically porous materials: Synthesis strategies and structure design. Chem. Soc. Rev. 2017, 46, 481-558. [CrossRef] [PubMed]

29. Naranda, J.; Sušec, M.; Maver, U.; Gradišnik, L.; Gorenjak, M.; Vukasović, A.; Ivković, A.; Rupnik, M.S.; Vogrin, M.; Krajnc, P. Polyester type polyHIPE scaffolds with an interconnected porous structure for cartilage regeneration. Sci. Rep. 2016, 6, 1-11. [CrossRef]

30. Lam, C.X.; Hutmacher, D.W.; Schantz, J.T.; Woodruff, M.A.; Teoh, S.H. Evaluation of polycaprolactone scaffold degradation for 6 months in vitro and in vivo. J. Biomed. Mater. Res. Part A Off. J. Soc. Biomater. Jpn. Soc. Biomater. Aust. Soc. Biomater. Korean Soc. Biomater. 2009, 90, 906-919.

31. Wang, Y.; Wan, X.; He, J.; Azhar, U.; Chen, H.; Zhao, J.; Pang, A.-m.; Geng, B. A one-step fabrication and modification of HIPE-templated fluoro-porous polymer using PEG-b-PHFBMA macrosurfactant. J. Mater. Sci. 2020, 55, 4970-4986. [CrossRef]

32. Wang, A.-j.; Paterson, T.; Owen, R.; Sherborne, C.; Dugan, J.; Li, J.-M.; Claeyssens, F. Photocurable high internal phase emulsions (HIPEs) containing hydroxyapatite for additive manufacture of tissue engineering scaffolds with multi-scale porosity. Mater. Sci. Eng. C 2016, 67, 51-58. [CrossRef]

33. Müller, K.H.; Motskin, M.; Philpott, A.J.; Routh, A.F.; Shanahan, C.M.; Duer, M.J.; Skepper, J.N. The effect of particle agglomeration on the formation of a surface-connected compartment induced by hydroxyapatite nanoparticles in human monocyte-derived macrophages. Biomaterials 2014, 35, 1074-1088. [CrossRef]

34. Deng, S.; Wang, Y.; Zhuang, G.; Zhong, X.; Wei, Z.; Yao, Z.; Wang, J.-G. Micromechanical simulation of the pore size effect on the structural stability of brittle porous materials with bicontinuous morphology. Phys. Chem. Chem. Phys. 2019, 21, 12895-12904. [CrossRef]

35. Dhand, C.; Ong, S.T.; Dwivedi, N.; Diaz, S.M.; Venugopal, J.R.; Navaneethan, B.; Fazil, M.H.; Liu, S.; Seitz, V.; Wintermantel, E. Bio-inspired in situ crosslinking and mineralization of electrospun collagen scaffolds for bone tissue engineering. Biomaterials 2016, 104, 323-338. [CrossRef]

36. Guo, X.; Gough, J.E.; Xiao, P.; Liu, J.; Shen, Z. Fabrication of nanostructured hydroxyapatite and analysis of human osteoblastic cellular response. J. Biomed. Mater. Res. Part A Off. J. Soc. Biomater. Jpn. Soc. Biomater. Aust. Soc. Biomater. Korean Soc. Biomater. 2007, 82, 1022-1032. [CrossRef] [PubMed] 